\title{
Prevention and treatment of venous
}

\section{thromboembolism in pregnancy in patients with hereditary antithrombin deficiency}

This article was published in the following Dove Press journal:

International Journal of Women's Health

2 May 2013

Number of times this article has been viewed

\author{
Andra H James' \\ Barbara A Konkle ${ }^{2,3}$ \\ Kenneth A Bauer ${ }^{4}$ \\ 'Department of Obstetrics and \\ Gynecology, University of Virginia, \\ Charlottesville, Virginia, ${ }^{2}$ Puget Sound \\ Blood Center, Seattle, Washington, \\ ${ }^{3}$ Department of Medicine, University \\ of Washington, Seattle, Washington, \\ ${ }^{4}$ Department of Medicine, Beth \\ Israel Deaconess Medical Center \\ and VA Boston Healthcare System, \\ Harvard Medical School, Boston, \\ Massachusetts, USA
}

Objective: The aims of the study reported here were to provide data from six pregnant subjects who were enrolled in a clinical trial of antithrombin (AT) concentrate, discuss other published case series and case reports, and provide general guidance for the use of AT concentrate for inherited AT deficiency in pregnancy.

Methods: In the late 1980s, 31 AT-deficient subjects were enrolled in a prospective treatment trial of the plasma-derived AT concentrate Thrombate III ${ }^{\circledR}$. Herein, newly available treatment data about the six pregnant subjects in the trial is tabulated and summarized.

Results: All six experienced venous thromboembolism (VTE) during pregnancy, were dosed according to a weight-based protocol, and were treated concomitantly with anticoagulation. Loading doses of AT concentrate of 54-62 units $/ \mathrm{kg}$ were followed by maintenance doses of $50 \%-100 \%$ of the loading dose for 3-10 days. At the time of labor, loading doses of $46-50$ units $/ \mathrm{kg}$ were followed by maintenance doses of $50 \%-75 \%$ of the loading dose for 5-7 days. None of the six experienced recurrent thrombosis while receiving treatment with AT concentrate.

Conclusion: Currently we suggest that women with AT deficiency who are pregnant or postpartum and have a personal history of VTE or current VTE receive AT concentrates.

Keywords: thrombophilia, thrombosis, plasma-derived concentrate, labor, delivery, heparin.

\section{Introduction}

During pregnancy, women have a four- to five-fold increased risk of thromboembolism compared with women who are not pregnant. ${ }^{1,2}$ Eighty percent of thromboembolic events in pregnancy are venous, ${ }^{3}$ with an absolute risk of venous thromboembolism (VTE) during pregnancy of between 0.5 and 2.0 per 1000 women..$^{3-9}$ The most important risk factor for VTE in pregnancy is a history of thrombosis. Besides this, the next most important risk factor for VTE in pregnancy is thrombophilia. ${ }^{3,10}$ Thrombophilia is present in $20 \%-50 \%{ }^{11-13}$ of women who experience VTE during pregnancy and the postpartum period.

Antithrombin (AT) deficiency was the first inherited thrombophilia to be described in 1965. ${ }^{14}$ Since then, multiple reports have documented the association between inherited AT deficiency and an increased rate of VTE. ${ }^{15}$ In pregnancy, the rate is correspondingly higher. Historic case series have reported rates of $18 \%-70 \%{ }^{16-18}$ The variation in these rates can be attributed to the relatively small numbers in each series and to the varied definitions of AT deficiency. Although a systematic review including more recent studies (some with more liberal thresholds of AT deficiency and not all requiring a positive family history) found a lower risk of thrombosis in pregnancy than did the initial studies (odds ratio 4.76 [95\% confidence interval 2.15, 10.57]); the high rates in
Correspondence: Andra $\mathrm{H}$ James University of Virginia, Department of Obstetrics and Gynecology, PO Box 8007 12, Charlottesville, VA, USA Tel + I 43498 I 1904

Email andra.james@virignia.edu 
the initial studies prompted obstetricians and hematologists to recommend full anticoagulation during pregnancy for women with AT deficiency. ${ }^{19,20}$ More recent recommendations from the American College of Chest Physicians do not endorse anticoagulation unless a woman has had a history of thrombosis, but continue to describe AT deficiency as a high-risk thrombophilia. ${ }^{21}$ Despite full anticoagulation during pregnancy and the postpartum period, women with AT deficiency are still vulnerable to developing VTE, particularly at the time of childbirth, when anticoagulation is withheld to prevent bleeding complications.

AT is a natural anticoagulant that inactivates thrombin by covalently binding to the active serine of thrombin and activated factor $\mathrm{X}(\mathrm{FXa}) .{ }^{15}$ AT can also inactivate other coagulation factors, including factors IXa, XIa, and XIIa ${ }^{15}$ (Figure 1). AT has a binding site for heparin and, in the absence of heparin, has low inhibitory activity against thrombin. In contrast, when heparin is present, inhibitory activity can be induced at least 1000 -fold. ${ }^{22}$ Importantly, in the absence of AT, heparin has little effect.

AT concentrates have been available since $1979 .{ }^{23}$ Of the two AT concentrates currently available, one is purified from human plasma (Thrombate III $^{\circledR}$, Grifols Therapeutics, Clayton, NC, USA) and the other is a recombinant product produced in transgenic goat mammary glands (ATryn ${ }^{\circledR}$, GTC Biotherapeutics, Framingham, MA, USA). Women with AT deficiency may be candidates for AT concentrates during pregnancy or the postpartum period when anticoagulation is desired, but contraindicated, for example during: invasive procedures such as egg retrieval, cerclage, chorionic villus sampling, or amniocentesis; miscarriages and ectopic

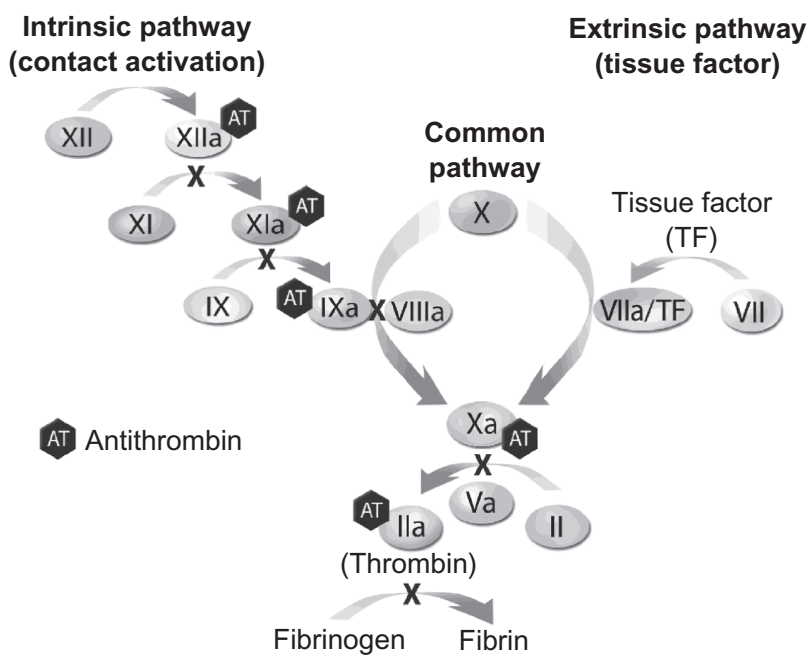

Figure I Antithrombin is inhibitory primarily to factors lla (thrombin) and $\mathrm{Xa}$ as well as, to a lesser extent, to factors IXa, Xla, Xlla, and VIla/TF. pregnancies; episodes of bleeding; surgical procedures; neuraxial anesthesia; childbirth, including cesarean delivery; postpartum tubal ligation; thrombocytopenia. AT concentrates can also be utilized to normalize antithrombin levels in women with current thrombosis or recurrent thrombosis despite anticoagulation.

AT deficiency is a rare disease affecting between 1 in $500^{27}$ and 1 in 5000 individuals, ${ }^{24}$ so large trials have not been conducted. The clinical trials that were conducted to obtain approval for AT concentrates were carried out on patients with inherited AT deficiency who were undergoing surgery or giving birth. In these small trials, ${ }^{26-28}$ efficacy was demonstrated by the low rate of thrombosis when anticoagulation was withheld during the perioperative or peripartum periods. Pregnant patients were included in these trials, but details that could provide guidance have not been published. The purpose of this paper is to provide detailed descriptions from six pregnant subjects in one of these trials, discuss the other published case series and case reports, and provide general guidance for the use of AT concentrates for inherited AT deficiency in pregnancy.

\section{Methods}

In the late 1980s, 31 AT-deficient subjects at high risk of thrombosis were enrolled in a prospective treatment trial of the plasma-derived AT concentrate Thrombate III $^{\circledR}{ }^{29}$ All participating sites had the approval of their respective institutional review boards. Of the 31 subjects, six were pregnant. Doses were based on the following formula:

$$
\begin{aligned}
& \text { Dose }(\text { in units })=(120 \% \text { minus basal } \% \text { of normal }) \\
&\text { multiplied by (weight in } \mathrm{kg}) /(1.4) .
\end{aligned}
$$

Plasma AT levels were generally measured 12 hours after the initial dose to ensure that the level remained above $80 \%{ }^{29}$ If necessary, a second dose of AT was administered at that time. Once predictable peak and trough levels were achieved, daily maintenance doses of the AT concentrate were administered in the amount of $60 \%$ of the loading dose in order to maintain plasma AT levels in the range of $70 \%-120 \%$ of normal. Although these six cases were mentioned in the publication from the original study, ${ }^{26}$ detailed descriptions were not published. Since that time, additional de-identified data have been made available by the sponsor. Detailed treatment data are provided in Table 1 and the cases are summarized in the "Results" section.

For the "Discussion," a computer-assisted search of the SciVerse Scopus electronic database (which includes Embase, MEDLINE, and MEDLINE Daily Updates) from 
1980 until February 2011 was conducted using different combinations of the following keywords: "antithrombin," "ATIII," "antithrombin deficiency," "pregnancy," "clinical study," "prospective study," "controlled study," "complications," "thrombophilia," "thrombosis," and "thrombotic complications."

\section{Results \\ Case I}

A 17-year-old woman with a strong family history of deep vein thrombosis (DVT) was admitted to the hospital at 20 weeks' gestation with right leg DVT and pulmonary embolism (PE). An emergency inferior vena caval ligation was performed and she subsequently received intravenous (IV) and, later, subcutaneous (sc) heparin for the duration of her pregnancy. She was admitted again at term for cesarean delivery. She was treated prophylactically with AT concentrate prior to delivery and for 6 days postpartum. The delivery and postpartum courses were uneventful, with no evidence of thrombosis.

\section{Case 2}

An 18-year-old woman was diagnosed with AT deficiency following DVT during her first trimester of pregnancy. Her plasma AT level was $38 \%$ at that time, and it was noted that both a brother and sister had histories of AT deficiency. She was maintained on sc heparin until admission for labor, when she was believed to be preeclamptic and in early labor. To raise her AT level, she received four units of fresh frozen plasma (FFP), but her plasma AT level remained at $48 \%$. Therefore, the patient was given a loading dose of AT concentrate and was continued on heparin. The next day she was started on a maintenance dose of AT concentrate for 5 days. Her delivery (vaginal) and remaining hospital course were uneventful.

\section{Case 3}

A 23-year-old woman with a strong family history of AT deficiency had been treated with chronic oral anticoagulation since 11 years of age. She discontinued warfarin therapy because of pregnancy, but 1 month later, in her eighth week of pregnancy, was admitted to the hospital with massive thrombosis of the left leg. IV heparin treatment over 26 hours failed to raise the activated partial thromboplastin time (aPTT) above 51.5 seconds. Therefore, AT concentrate was administered with a loading dose. A daily maintenance course for 3 days was followed by a twice-weekly course with sc heparin over 19 days. Despite this regimen, her trough plasma AT levels dropped to 50\%-60\%. Therefore, her AT concentrate dose was increased, resulting in trough plasma levels generally remaining above $70 \%$. Subsequently, she was maintained on the new dose twice weekly with sc heparin every 8 hours for the entire duration of the pregnancy as well as postpartum, when she was bridged to oral anticoagulant therapy. The delivery (vaginal) was uneventful, without thrombotic complications.

\section{Case 4}

A 27-year-old woman, with known AT deficiency, was admitted to the hospital at 12 weeks' gestation with PE and right upper lobe pulmonary infarction. She had a strong family history of AT deficiency, with eight maternal aunts and uncles with documented AT deficiency, mostly with recurrent VTE. The patient was treated with two units of FFP and started on IV heparin after receiving a bolus. However, heparin treatment caused only transient increases in the aPTT, despite administration of another bolus within 12 hours. Therefore, AT concentrate was initiated with a loading dose, which increased the plasma AT level from 50\% to $110 \%$. The aPTT lengthened to 68 seconds, and subsequent measurements demonstrated much less variability than had been noted prior to initiating AT concentrate therapy. Within 3 days, the patient was symptomatically much improved. She continued to receive IV heparin and AT concentrate for 10 days. A maintenance program was begun that consisted of sc heparin and AT concentrate twice weekly. Ultimately, the aPTT, measured just prior to each AT dose, stabilized at $>50$ seconds and the AT concentrate was discontinued 41 days after initiation of therapy. After 1 month, AT concentrate therapy was resumed once weekly along with sc heparin. This regimen was continued until 4 weeks prior to delivery, after which the dosing frequency was increased to twice weekly. The delivery (vaginal) was uneventful, without thrombotic complications.

\section{Case 5}

A 28-year-old woman was first treated for bilateral DVT at 20 years of age. Approximately 6 years later, she became pregnant, at which time her warfarin treatment was stopped and sc heparin substituted, but she miscarried 1 week later. During follow-up, her plasma AT level was found to be as low as $18 \%$. She became pregnant again 2 months later and was switched from warfarin to sc heparin every 8 hours. At approximately 9 weeks' gestation, she presented with a 2-day history of right thigh pain. She was diagnosed as having acute DVT, with laboratory parameters indicating 
Table I Details of treatment of six antithrombin (AT)-deficient pregnant patients

\begin{tabular}{llllll}
\hline Case & Age, years & Parity & Basis for diagnosis & $\begin{array}{l}\text { Indication for treatment with AT } \\
\text { during pregnancy }\end{array}$ & $\begin{array}{l}\text { Plasma AT level prior to initial } \\
\text { AT treatment (\%) }\end{array}$ \\
\hline 1 & 17 & 0 & Strong family history of DVT & $\begin{array}{l}\text { DVT R leg and PE at } \\
20 \text { weeks' gestation }\end{array}$ & 59
\end{tabular}

18

23

27

28

35
0

Strong family history

Strong family history

0

0

0
DVT early pregnancy (also with strong family history)

5

6
DVT age 20. Diagnosed after miscarriage on Coumadin

DVT and PE at age 23 and strong family history
DVT early pregnancy

Massive DVT L leg at

8 weeks' gestation

PE at 12 weeks' gestation

DVT R leg 8 weeks' gestation

PE I2 weeks' gestation
50

38 at time of diagnosis

50

42

Abbreviations: DVT, deep vein thrombosis; FFP, fresh frozen plasma; IV, intravenous; IVC, inferior vena cava; L, left leg; PE, pulmonary embolism; PP, postpartum; R, right leg; sc, subcutaneous.

active disseminated intravascular coagulation. Following treatment with FFP, her plasma AT level was only 30\%-46\%. Her heparin therapy was discontinued, she was switched back to warfarin, and treatment with AT concentrate was started. A loading dose was followed with daily maintenance doses for the following 7 days. She then underwent termination of pregnancy without incident. Her DVT rapidly improved during treatment and she was discharged on warfarin anticoagulation.

\section{Case 6}

A 35-year-old woman with a history of DVT and PE at 23 years of age, as well as a family history of thrombosis (two sisters, a mother, and aunt had recurrent VTE), was admitted with PE at 12 weeks' gestation. Her plasma AT level was $58 \%$. While being treated with heparin, she developed recurrent PE and was found to be heparin resistant. IV heparin was administered when her plasma AT level was $43 \%$ and she was continued concomitantly on AT concentrate. She received a total of twelve daily infusions of AT concentrate. All infusions were well tolerated. Termination of pregnancy was performed 1 week after initiation of treatment. She was discharged 4 days later on warfarin therapy.

\section{Summary}

In this case series, the patients ranged in age from 17 to 35 years. None had given birth previously. Five of the six had a strong family history of AT deficiency and VTE. All of these patients developed and were treated for VTE during pregnancy. Except for one patient who was diagnosed in the current pregnancy and had an AT level of $18 \%$, AT levels at the time of initial treatment ranged from $38 \%$ to $59 \%$. Besides full anticoagulation with IV or sc heparin, four of the six patients were treated with plasma-derived AT concentrate at the time of diagnosis of VTE, two after receiving FFP. Loading doses of AT concentrate of 54-62 units $/ \mathrm{kg}$ were administered. This was 


\begin{tabular}{|c|c|c|c|}
\hline Treatment in pregnancy & Weeks' gestation & Mode of delivery & $\begin{array}{l}\text { Summary of procedures or AT } \\
\text { concentrate for delivery }\end{array}$ \\
\hline IVC ligation, IV and sc heparin & Term & Cesarean & $\begin{array}{l}\text { Admitted at full-term for delivery. Given } \\
50 \text { units/kg loading dose. Repeated } 72 \text { h later. } \\
\text { Heparin discontinued and cesarean performed. } \\
25 \text { units/kg daily } \times 7 \text { days thereafter. Heparin } \\
\text { restarted } 2 \text { days PP. Coumadin started } 4 \text { days } \\
\text { PP. Nadir AT levels prior to dosing were all } \\
\text { approximately } 80 \% \text {. Discharged on Coumadin }{ }^{\circledR} \\
\text { (Bristol-Myers Squibb, New York, NY, USA) }\end{array}$ \\
\hline sc heparin & Term & Vaginal & $\begin{array}{l}\text { Admitted in early labor with preeclampsia. } \\
4 \text { units FFP on admission, AT level still only } 48 \% \text {. } \\
\text { Given AT } 46 \text { units } / \mathrm{kg} \text { loading dose. Maintenance } \\
\text { of } 34 \text { units } / \mathrm{kg} \times 24 \text { hours then } 23 \text { units } / \mathrm{kg} \\
\text { daily } \times 5 \text { days. AT levels } 64 \%-122 \%\end{array}$ \\
\hline $\begin{array}{l}\text { IV heparin plus AT } 54 \text { units } / \mathrm{kg} \text { loading dose, then } \\
3 \text { I units } / \mathrm{kg}(60 \% \text { of loading dose) } \times 3 \text { days, } \\
\text { followed by } 54 \text { units } / \mathrm{kg} \text { twice weekly plus sc } \\
\text { heparin. Then sc heparin plus AT concentrate } \\
\text { increased to } 72-76 \text { units } / \mathrm{kg} \text { twice weekly to } \\
\text { maintain nadir plasma AT levels }>70 \%\end{array}$ & Term & Vaginal & Coumadin PP \\
\hline $\begin{array}{l}2 \text { units of FFP on admission. IV heparin plus AT } \\
50 \text { units } / \mathrm{kg} \text { loading dose, then } 33-50 \text { units } / \mathrm{kg} \times \\
\text { I0 days. Then AT } 40-66 \text { units } / \mathrm{kg} \text { twice weekly } \\
\text { for I more month with sc heparin. Plasma nadir } \\
\text { AT levels remained }>66 \% \text {. AT was discontinued } \\
\text { for I month and resumed at } 62 \text { units } / \mathrm{kg} \text { once } \\
\text { weekly with sc heparin }\end{array}$ & Term & Vaginal & $\begin{array}{l}\text { AT } 62 \text { units } / \mathrm{kg} \text { increased to twice weekly in the } \\
4 \text { weeks prior to delivery. Coumadin PP }\end{array}$ \\
\hline $\begin{array}{l}\text { FFP on admission. AT level still only } 30 \%-46 \% \text {. } \\
\text { AT } 62 \text { units } / \mathrm{kg} \text { loading dose. Daily maintenance } \\
\text { doses of } 38-39 \text { units } / \mathrm{kg}\end{array}$ & 9 & $\begin{array}{l}\text { Termination of } \\
\text { pregnancy }\end{array}$ & Discharged on Coumadin \\
\hline $\begin{array}{l}\text { IV heparin plus AT } 58.5 \text { units } / \mathrm{kg} \text { daily } \times 3 \text { days then } \\
29.3 \text { units } / \mathrm{kg} \times 8 \text { days, then } 58.5 \text { units } \times I \text { day }\end{array}$ & 13 & $\begin{array}{l}\text { Termination of } \\
\text { pregnancy }\end{array}$ & $\begin{array}{l}\text { Termination of pregnancy after I week of } \\
\text { therapy. Discharged } 4 \text { days later on Coumadin }\end{array}$ \\
\hline
\end{tabular}

followed by a maintenance dose of $50 \%-100 \%$ of the loading dose for 3-10 days. Two of the four women who received AT concentrate terminated their pregnancies. The other two received an extended course with twice-weekly infusions 62 units $/ \mathrm{kg}$ in one case and 72-76 units/kg in the other - to maintain trough plasma AT levels $>70 \%$. One patient (who did not receive either FFP or AT concentrate) underwent inferior vena caval ligation. She and the other remaining woman only received AT concentrate at the time of labor, with a loading dose of 46-50 units/ $\mathrm{kg}$ followed by a maintenance dose of $50 \%-75 \%$ of the loading dose for 5-7 days. None of the women experienced recurrent thrombosis while receiving treatment with AT concentrate (Table 1).

\section{Discussion}

In this case series of difficult-to-manage AT-deficient women with new-onset or recurrent thrombosis during pregnancy, plasma-derived AT concentrate was administered to normalize AT levels during initial treatment of VTE or to provide thromboprophylaxis when anticoagulation was withheld at the time of childbirth. AT concentrate was well tolerated and none of the women experienced recurrent thrombosis while receiving treatment. Loading doses and maintenance doses were prescribed according to protocol, which succeeded in raising AT levels to $\geq 60 \mathrm{IU} / \mathrm{dL}$.

Other studies of pregnant patients with hereditary AT deficiency have been published. Two reported on pregnancy outcomes in cohorts of women with AT deficiency, ${ }^{32,33}$ one reported on the prevalence of AT deficiency among women with pregnancy-related VTE, ${ }^{34}$ and a number of case series and case reports have reported specifically on the course and treatment during pregnancy of women with AT deficiency $^{27,28,32-45}$ (Table 2). Different regimens have been used for antepartum and peripartum thromboprophylaxis. Between 1981 and 1992, the published regimens for antepartum thromboprophylaxis or treatment were for sc heparin or oral 
Table 2 Course and treatment during pregnancy of women with antithrombin (AT) deficiency

\begin{tabular}{|c|c|c|c|c|c|c|c|}
\hline & $\begin{array}{l}\text { Pregnancies, } \\
\text { n }\end{array}$ & Hx VTE & $\begin{array}{l}\text { Current } \\
\text { VTE }\end{array}$ & $\begin{array}{l}\text { Baseline AT } \\
\text { levels }\end{array}$ & $\begin{array}{l}\text { Antepartum } \\
\text { prophylaxis }\end{array}$ & $\begin{array}{l}\text { Recurrent } \\
\text { VTE }\end{array}$ & $\begin{array}{l}\text { Peripartum AT } \\
\text { concentrate }\end{array}$ \\
\hline Brandt $^{32}$ & 2 & I & - & $50 \%, 65 \%$ & sc heparin & 0 & 550 units \\
\hline $\begin{array}{l}\text { Hellgren } \\
\text { et } \mathrm{al}^{16}\end{array}$ & 9 & 2 & - & $39 \%-52 \%$ & sc heparin & 1 & $\begin{array}{l}2000-5000 \text { units (average } \\
\text { dose } 4 \text { I units per } \mathrm{kg} \text { [range } \\
37-46] \text { ) per infusion to } \\
\text { maintain AT levels of } \geq 80 \%\end{array}$ \\
\hline $\begin{array}{l}\text { Michiels } \\
\text { et } \mathrm{al}^{34}\end{array}$ & 2 & 0 & - & $42 \%, 55 \%$ & Oral anticoagulants & 0 & 3000 units $(1$ of 2$)$ \\
\hline $\begin{array}{l}\text { Samson } \\
\text { et } \mathrm{al}^{35}\end{array}$ & 1 & I & 0 & $20 \%$ & sc heparin & 0 & $\begin{array}{l}3000 \text { units loading dose } \\
\text { (50 units per } \mathrm{kg} \text { ); I } 500 \text { units } \\
\text { ( } 25 \text { units per } \mathrm{kg} \text { ) } 48 \mathrm{~h} \text { later, } \\
\text { then doses adjusted and } \\
\text { repeated every } 48 \mathrm{~h} \text { to } \\
\text { maintain AT levels } \geq 80 \%\end{array}$ \\
\hline De Stefano ${ }^{36}$ & 4 & 2 & I & "Around 50\%" & $\begin{array}{l}\text { sc heparin + oral } \\
\text { anticoagulants }\end{array}$ & 0 & $2500-3500$ units \\
\hline $\begin{array}{l}\text { Menache } \\
\text { et } \mathrm{al}^{27}\end{array}$ & 5 & 2 & I & $29 \%-65 \%$ & - & 0 & $\begin{array}{l}5-6 \text { daily infusions of } \\
30.4 \text { to } 93.0 \mathrm{IU} / \mathrm{kg}\end{array}$ \\
\hline $\begin{array}{l}\text { Blondel-Hill } \\
\text { and Mant }{ }^{37}\end{array}$ & 2 & 2 & 0 & $46 \%, 62 \%$ & sc heparin & I & 6 units FFP (I of 2$)$ \\
\hline Kario et $\mathrm{al}^{38}$ & I & I & 0 & - & $\begin{array}{l}3000 \text { units AT concentrate } \\
3 \times \text { per week starting at } \\
34 \text { weeks' gestation }\end{array}$ & 0 & \\
\hline $\begin{array}{l}\text { Yamada } \\
\text { et } \mathrm{al}^{39}\end{array}$ & 2 & 2 & 0 & $50 \%, 59 \%$ & $\begin{array}{l}6000 \text { units AT concentrate } \\
\text { (I) and heparin }+ \\
\text { I500 units AT concentrate (I }\end{array}$ & I & \\
\hline $\begin{array}{l}\text { Grandone } \\
\text { et } \mathrm{al}^{40}\end{array}$ & 15 & $\begin{array}{l}\mathrm{I} / 3 \\
\text { women }\end{array}$ & & - & - & 0 & None \\
\hline $\begin{array}{l}\text { Tiede } \\
\text { et } \mathrm{al}^{28}\end{array}$ & 9 & 7 & 0 & $33 \%-58 \%$ & & & $\begin{array}{l}\text { Loading dose } 2 \mathrm{I}-8 \mathrm{I} \text { units } \\
\text { per } \mathrm{kg} \text { recombinant AT, } \\
\text { maintenance infusions of } \\
160-436 \mathrm{IU} / \mathrm{kg} / \text { day } \times \\
3-10 \text { days }\end{array}$ \\
\hline $\begin{array}{l}\text { Hidaka } \\
\text { et } \mathrm{al}^{41}\end{array}$ & I & I & I & $31 \%$ & $\begin{array}{l}\text { sc heparin }+3000 \text { units } \\
\text { AT concentrate } 2-3 \times \\
\text { per week target } \geq 70 \%\end{array}$ & 1 & \\
\hline $\begin{array}{l}\text { Sabadell } \\
\text { et } \mathrm{al}^{42}\end{array}$ & 18 & $\begin{array}{l}5 / 9 \\
\text { women }\end{array}$ & $\begin{array}{l}3 \text { (untreated } \\
\text { pregnancies) }\end{array}$ & $33 \%-57 \%$ & I2/I8 with LMWH & 0 & "In labor" \\
\hline $\begin{array}{l}\text { Pamnani } \\
\text { et } \mathrm{al}^{43}\end{array}$ & I & I & 0 & $54 \%$ & LMWH & 0 & $\begin{array}{l}3091 \text { units recombinant } \\
\text { AT followed by } 712 \text { units } \\
\text { per hour }\end{array}$ \\
\hline $\begin{array}{l}\text { Sharpe } \\
\text { et } \mathrm{al}^{44}\end{array}$ & I & I & I & $38 \%$ & $\begin{array}{l}\text { LMWH + AT concentrate } \\
2000-3000 \text { units per day } \\
\text { after sagittal vein } \\
\text { thrombosis at } 34 \text { weeks }\end{array}$ & & $\begin{array}{l}3000 \text { units } \times 3 \text { days at } \\
\text { delivery then } 2000-3000 \\
\text { units per day } \times 6 \text { weeks }\end{array}$ \\
\hline Kovac et $\mathrm{al}^{45}$ & I & I & 0 & $33 \%$ & LMWH & 0 & I dose 50 units per kg \\
\hline
\end{tabular}

Abbreviations: Hx VTE, medical history of venous thromboembolism; LMWH, low-molecular-weight heparin; VTE, venous thromboembolism; sc, subcutaneous.

anticoagulants..$^{27,32-37}$ Subsequently, the only anticoagulant used alone for antepartum prophylaxis was low-molecularweight heparin. ${ }^{42-45}$ There were two reports from Japan of AT concentrate being used for antepartum thromboprophylaxis. In two cases it was used alone, ${ }^{38}$ and in one case it was used with heparin. ${ }^{39}$ In one case, AT concentrate was used in conjunction with sc heparin for the treatment of VTE. ${ }^{41}$ In one report, no AT concentrate was given at the time of delivery, ${ }^{40}$ while, in another report, FFP was given but no AT concentrate. ${ }^{37}$ In five reports, peripartum AT concentrate was given just at the time of delivery ${ }^{32,34,36,42,45}$ and in another five, AT concentrate was given for several days surrounding the time of delivery. ${ }^{16,27,28,35,43}$ One study reported the administration of AT concentrate for 6 weeks postpartum. ${ }^{44}$ When doses 
were repeated, they were repeated at varying intervals (eg, daily, every 48 hours, two times per week, three times per week). When AT concentrate was administered, in twelve reports, plasma-derived concentrate was used ( $n=47$ cases) and in two reports recombinant concentrate was used $(n=10$ cases). For plasma-derived AT concentrate, reported doses ranged from 550 to 6000 units or were weight-based. In one report, loading doses of 50 units/kg were administered, with maintenance doses of 25 units/kg every 48 hours. For recombinant AT concentrate, loading doses ranged from 21 to 81 units/kg and maintenance infusions ranged from 160 to 436 $\mathrm{IU} / \mathrm{kg} /$ day and were administered for 3-10 days ${ }^{29}$ or, in one case report, 3091 units followed by a maintenance infusion of 712 units per hour. ${ }^{43}$ As for indications, only 29/53 cases had a personal history of VTE, with the others diagnosed with AT deficiency based on a family history. Fewer (four) had current VTE. ${ }^{19,30,31,35,37-39-48}$

Plasma-derived AT concentrates are well tolerated, with minimal adverse reactions, and pose an extremely low risk for transmission of infectious agents. (There have been no confirmed reports of infectious transmission with Thrombate III $\left.{ }^{\circledR}\right)$. The initial dose is calculated as: initial dose $=([$ desired AT level - current AT level $] \times$ weight in $\mathrm{kg}$ )/1.4. Maintenance doses are then calculated using approximately $60 \%$ of the loading dose and are given once every 24 hours to maintain peak and trough AT activity levels in the range of $80 \%$ and $120 \%$, respectively. ${ }^{15}$

With minor glycosylation differences, recombinant AT has an identical amino acid structure to endogenous AT. Differences in glycosylation, however, do not appear to elicit immune reactions. The clinical difference is in the mean half-life, which is estimated to be $10.49 \pm 7.19$ hours for recombinant AT, in comparison to 56.8-68.0 hours for plasma-derived AT. ${ }^{15}$ Therefore, recombinant AT is administered as a continuous infusion. In a study by Tiede et al, the initial dose was calculated as: ([100 - pretreatment AT activity level in \%] $\times$ body weight in $\mathrm{kg}) / 2.28$. Maintenance infusion (IU/h) is then calculated as: ([100 - pretreatment AT activity level in \%] $\times$ body weight in $\mathrm{kg}$ ) $/ 10.22 .{ }^{28}$ The prescribing information for ATryn provided by GTC Biotherapeutics has the loading dose in pregnancy as: ([100 - baseline AT activity] $\times$ body weight in $\mathrm{kg}) / 1.3$. The maintenance infusion (IU/hr) is: ([100 - baseline AT activity] $\times$ body weight in $\mathrm{kg}) / 5.4{ }^{46}$

\section{Conclusion}

In contrast to the other reports in the literature, the six patients discussed here each had a personal history of VTE, were dosed according to a weight-based protocol, and were treated concomitantly with anticoagulation. Limitations of this series are the relatively small number of cases and the fact that the cases were treated some time ago with anticoagulation regimens that have been replaced by lowmolecular-weight heparin. Despite the fact that the series comprises only six cases, this is one of the larger series, and, as is true for other rare diseases for which randomized trials and even large cohort studies are unavailable, small case series or even individual cases can be instructive. Otherwise, there are few data and little guidance on the management of AT concentrates in pregnancy and at the time of delivery. General guidance regarding dosing has been provided here. Our current guidance would be that women with AT deficiency who are pregnant or postpartum and have a personal history of VTE or new-onset or recurrent VTE receive AT concentrates. We would suggest that women with low levels of AT $(<60 \%)$ with a compelling family history, and those with very low levels of AT $(<40 \%)$, also receive AT concentrates.

\section{Acknowledgment}

Detailed cases histories and a systematic review of the literature were provided by Grifols.

\section{Disclosure}

The authors declare no conflicts of interest in this work.

\section{References}

1. Heit JA, Kobbervig CE, James AH, Petterson TM, Bailey KR, Melton LJ 3rd. Trends in the incidence of venous thromboembolism during pregnancy or postpartum: a 30-year population-based study. Ann Intern Med. 2005;143(10):697-706.

2. Pomp ER, Lenselink AM, Rosendaal FR, Doggen CJ. Pregnancy, the postpartum period and prothrombotic defects: risk of venous thrombosis in the MEGA study. J Thromb Haemost. 2008;6(4): 632-637.

3. James AH, Jamison MG, Brancazio LR, Myers ER. Venous thromboembolism during pregnancy and the postpartum period: incidence, risk factors, and mortality. Am J Obstet Gynecol. 2006;194(5): 1311-1315.

4. Andersen BS, Steffensen FH, Sorensen HT, Nielsen GL, Olsen J. The cumulative incidence of venous thromboembolism during pregnancy and puerperium - an 11 year Danish population-based study of 63,300 pregnancies. Acta Obstet Gynecol Scand. 1998;77(2):170-173.

5. Gherman RB, Goodwin TM, Leung B, Byrne JD, Hethumumi R, Montoro M. Incidence, clinical characteristics, and timing of objectively diagnosed venous thromboembolism during pregnancy. Obstet Gynecol. 1999;94(5 Pt 1):730-734.

6. Lindqvist P, Dahlbäck B, Marsál K. Thrombotic risk during pregnancy: a population study. Obstet Gynecol. 1999;94(4):595-599.

7. Simpson EL, Lawrenson RA, Nightingale AL, Farmer RD. Venous thromboembolism in pregnancy and the puerperium: incidence and additional risk factors from a London perinatal database. BJOG. 2001; 108(1):56-60. 
8. Jacobsen AF, Skjeldestad FE, Sandset PM. Incidence and risk patterns of venous thromboembolism in pregnancy and puerperium - a register-based case-control study. Am J Obstet Gynecol. 2008;198(2):233. e1-e7.

9. Liu S, Rouleau J, Joseph KS, et al; Maternal Health Study Group of the Canadian Perinatal Surveillance System. Epidemiology of pregnancyassociated venous thromboembolism: a population-based study in Canada. J Obstet Gynaecol Can. 2009;31(7):611-620.

10. James AH, Tapson VF, Goldhaber SZ. Thrombosis during pregnancy and the postpartum period. Am J Obstet Gynecol. 2005;193(1):216-219.

11. De Stefano V, Simioni P, Rossi E, et al. The risk of recurrent venous thromboembolism in patients with inherited deficiency of natural anticoagulants antithrombin, protein $\mathrm{C}$ and protein S. Haematologica. 2006;91(5):695-698.

12. Dilley A, Austin H, El-Jamil M, et al. Genetic factors associated with thrombosis in pregnancy in a United States population. Am J Obstet Gynecol. 2000;183(5):1271-1277.

13. Gerhardt A, Scharf RE, Beckmann MW, et al. Prothrombin and factor V mutations in women with a history of thrombosis during pregnancy and the puerperium. N Engl J Med. 2000;342(6):374-380.

14. Egeberg O. Thrombophilia caused by inheritable deficiency of blood antithrombin. Scand J Clin Lab Invest. 1965;17:92.

15. Patnaik MM, Moll S. Inherited antithrombin deficiency: a review. Haemophilia. 2008;14(6):1229-1239.

16. Hellgren M, Tengborn L, Abildgaard U. Pregnancy in women with congenital antithrombin III deficiency: experience of treatment with heparin and antithrombin. Gynecol Obstet Invest. 1982;14(2):127-141.

17. Conard J,Horellou MH, VanDreden P,LecompteT, Samama M.Thrombosis and pregnancy in congenital deficiencies in AT III, protein C or protein S: study of 78 women. Thromb Haemost. 1990;63(2):319-320.

18. Pabinger I, Schneider B. Thrombotic risk in hereditary antithrombin III, protein $\mathrm{C}$, or protein $\mathrm{S}$ deficiency. A cooperative, retrospective study. Gesellschaft fur Thrombose- und Hamostaseforschung (GTH) Study Group on Natural Inhibitors. Arterioscler Thromb Vasc Biol. 1996; 16(6):742-748.

19. JamesA; Committee on Practice Bulletins-Obstetrics. Practice bulletin no 123: thromboembolism in pregnancy. Obstet Gynecol. 2011;118(3): 718-729.

20. Bates SM, Greer IA, Pabinger I, Sofaer S, Hirsh J; American College of Chest Physicians. Venous thromboembolism, thrombophilia, antithrombotic therapy, and pregnancy: American College of Chest Physicians Evidence-Based Clinical Practice Guidelines, 8th ed. Chest. 2008;133(Suppl 6):844S-886S.

21. Bates SM, Greer IA, Middeldorp S, Veenstra DL, Prabulos AM, Vandvik PO; American College of Chest Physicians. VTE, thrombophilia, antithrombotic therapy, and pregnancy: Antithrombotic Therapy and Prevention of Thrombosis, 9th ed. American College of Chest Physicians Evidence-Based Clinical Practice Guidelines. Chest. 2012;141(Suppl 2):e691S-e736S.

22. Jordan RE, Oosta GM, Gardner WT, Rosenberg RD. The kinetics of hemostatic enzyme-antithrombin interactions in the presence of low molecular weight heparin. J Biol Chem. 1980;255(21):10081-10090.

23. Wickerhauser M, Williams C, Mercer J. Development of large scale fractionation methods. VII. Preparation of antithrombin III concentrate. Vox Sang. 1979;36(5):281-293.

24. Finazzi G, Caccia R, Barbui T. Different prevalence of thromboembolism in the subtypes of congenital antithrombin III deficiency: review of 404 cases. Thromb Haemost. 1987;58(4):1094.

25. Tait RC, Walker ID, Islam SI, et al. Influence of demographic factors on antithrombin III activity in a healthy population. $\mathrm{Br} J$ Haematol. 1993;84(3):476-480.

26. Schwartz RS, Bauer KA, Rosenberg RD, Kavanaugh EJ, Davies DC, Bogdanoff DA. Clinical experience with antithrombin III concentrate in treatment of congenital and acquired deficiency of antithrombin. The Antithrombin III Study Group. Am J Med. 1989;87(3B):53S-60S.

27. Menache D, O'Malley JP, Schorr JB, et al. Evaluation of the safety, recovery, half-life, and clinical efficacy of antithrombin III (human) in patients with hereditary antithrombin III deficiency. Cooperative Study Group. Cooperative Study Group. Blood. 1990; 75(1):33-39.
28. Tiede A, Tait RC, Shaffer DW, et al. Antithrombin alfa in hereditary antithrombin deficient patients: A phase 3 study of prophylactic intravenous administration in high risk situations. Thromb Haemost. 2008;99(3):616-622.

29. Sanson BJ, Friederich PW, Simioni P, et al. The risk of abortion and stillbirth in antithrombin-, protein C-, and protein S-deficient women. Thromb Haemost. 1996;75(3):387-388.

30. Friederich PW, Sanson BJ, Simioni P, et al. Frequency of pregnancyrelated venous thromboembolism in anticoagulant factor-deficient women: implications for prophylaxis. Ann Intern Med. 1996; 125(12):955-960.

31. Martinelli I, De Stefano V, Taioli E, Paciaroni K, Rossi E, Mannucci PM. Inherited thrombophilia and first venous thromboembolism during pregnancy and puerperium. Thromb Haemost. 2002;87(5):791-795.

32. Brandt P. Observations during the treatment of antithrombin-III deficient women with heparin and antithrombin concentrate during pregnancy, parturition, and abortion. Thromb Res. 1981;22(1-2):15-24.

33. Hellgren M, Nygårds EB. Long-term therapy with subcutaneous heparin during pregnancy. Gynecol Obstet Invest. 1982;13(2):76-89.

34. Michiels JJ, Stibbe J, Vellenga E, van Vliet HH. Prophylaxis of thrombosis in antithrombin III-deficient women during pregnancy and delivery. Eur J Obstet Gynecol Reprod Biol. 1984;18(3):149-153.

35. Samson D, Stirling Y, Woolf L, Howarth D, Seghatchian MJ, de Chazal R. Management of planned pregnancy in a patient with congenital antithrombin III deficiency. Br J Haematol. 1984;56(2): 243-249.

36. De Stefano V, Leone G, De Carolis S, et al. Management of pregnancy in women with antithrombin III congenital defect: report of four cases. Thromb Haemost. 1988;59(2):193-196.

37. Blondel-Hill E, Mant MJ. The pregnant antithrombin III deficient patient: management without antithrombin III concentrate. Thromb Res. 1992;65(2):193-198.

38. Kario K, Matsuo T, Kodama K, Matsuo M. Prophylactic antithrombin III administration during pregnancy immediately reduces the thrombin hyperactivity of congenital antithrombin III deficiency by forming thrombin-antithrombin III complexes. Thromb Res. 1992;66(5): 509-515.

39. Yamada T, Yamada H, Morikawa M, et al. Management of pregnancy with congenital antithrombin III deficiency: two case reports and a review of the literature. J Obstet Gynaecol Res. 2001;27(4):189-197.

40. Grandone E, De Stefano V, Rossi E, Cappucci F, Colaizzo D, Margaglione M. Antithrombotic prophylaxis during pregnancy in women with deficiency of natural anticoagulants. Blood Coagul Fibrinolysis. 2008;19(3):226-230.

41. Hidaka N, Hachisuga M, Tsukimori K, Onohara T, Maehara Y, Wake N. Intrapartum placement of an inferior vena cava filter for a woman with hereditary antithrombin III deficiency: its role in the prevention of fatal pulmonary embolism. J Obstet Gynaecol Res. 2008;34(1):95-99.

42. Sabadell J, Casellas M, Alijotas-Reig J, Arellano-Rodrigo E, Cabero L. Inherited antithrombin deficiency and pregnancy: maternal and fetal outcomes. Eur J Obstet Gynecol Reprod Biol. 2010;149(1):47-51.

43. Pamnani A, Rosenstein M, Darwich A, Wolfson A. Neuraxial anesthesia for labor and cesarean delivery in a parturient with hereditary antithrombin deficiency on recombinant human antithrombin infusion therapy. J Clin Anesth. 2010;22(6):450-453.

44. Sharpe CJ, Crowther MA, Webert KE, Donnery C. Cerebral venous thrombosis during pregnancy in the setting of type I antithrombin deficiency: case report and literature review. Transfus Med Rev. 2011; 25(1):61-65.

45. Kovac M, Miković Z, Rakirević L, et al. A successful outcome of pregnancy in a patient with congenital antithrombin deficiency. Vojnosanit Pregl. 2011;68(2):175-177.

46. Atryn (Recombinant) Highlights of Prescribing Information US. GTC Biotherapeutics, Inc. Framingham, MA, USA. November, 2010. Available at http://atryn.com/pdf/ATryn_PI_0409.pdf. Accessed April 21, 2013. 
International Journal of Women's Health

Dovepress

\section{Publish your work in this journal}

The International Journal of Women's Health is an international, peerreviewed open-access journal publishing original research, reports, editorials, reviews and commentaries on all aspects of women's healthcare including gynecology, obstetrics, and breast cancer. The manuscript management system is completely online and includes Visit http://www.dovepress.com/testimonials.php to read real quotes from published authors.

Submit your manuscript here: http://www.dovepress.com/international-journal-of-womens-health-journal 